Matko Matija Marušić

Institut za povijest umjetnosti, Zagreb

\title{
Urbani krajolik i vlasnička topografija kasnosrednjovjekovnog Dubrovnika prema seriji Venditiones Cancellariae
}

\author{
Izvorni znanstveni rad - Original scientific paper \\ Primljen 20. 6. 2017.
}

UDK 347.451.4(497.5Dubrovnik)"1352/1454"

\begin{abstract}
Sažetak
Ovaj rad za cilj ima predstaviti istraživanje tzv. kancelarijskih prodaja nekretnina u Dubrovniku izmedu 1352. i 1454. godine. U fokusu je prvih trinaest knjiga serije Venditiones Cancellariae $u$ Državnom arhivu u Dubrovniku koje obuhvaćaju zapise o prodajama u drugoj polovini četrnaestog i prvoj polovini petnaestog stoljeća. Uz pregled
\end{abstract}

osnovnih podataka o sadržaju tih svezaka i tipovima dokumenata koji se u njima nalaze, na izabranim će se primjerima nastojati ukazati na važnost te nedovoljno poznate građe za istraživanja o vlasništvu $i$ prometu nekretnina te, posredno, o urbanističkom razvoju Dubrovnika.

Ključne riječi: urbana povijest, vlasnička topografija, urbani razvoj, kupoprodajni ugovori, Venditiones Cancellariae, Državni arhiv u Dubrovniku

Državni arhiv u Dubrovniku još uvijek čuva građu iz razdoblja Dubrovačke Republike za koju s punim pravom možemo ustvrditi da nije dovoljno istražena te da podaci koji su ondje zabilježeni mogu pružiti niz novih historiografskih uvida. Toj skupini vrela nesumnjivo pripadaju registri prodaja dubrovačke kancelarije, Venditiones Cancellariae, ustanovljeni 1352. godine, u vrijeme vladavine kneza Nikole Volpa. Premda razloge tog poteza tek predstoji podrobnije istražiti, očita namjera uspostavljanja zasebnoga javnog registra prodaja bila je da se dokumenti vezani za nekretninsku trgovinu izdvoje iz cjeline Diversa Cancellariae. ${ }^{1}$ U ukupno 161 svesku serije Venditiones Cancellariae sačuvane su zabilježbe kupoprodajnih transakcija nepokretne i pokretne imovine (zemljišta, kuće, brodovi itd.) od sredine četrnaestog stoljeća do pada Republike, kako u Gradu tako i u izvangradskom području.

Nalazimo se, dakle, pred građom koja pruža pregršt podataka o topografiji grada i vlasničkim strukturama, što ovu arhivsku cjelinu čini nezaobilaznim vrelom za proučavanje razvoja i mijena urbane slike Dubrovnika te trgovanja prostorima i građevinama, prvenstveno kućama i zemljištima. Imajući u vidu taj segment dubrovačke prošlosti, u ovome ću radu analizirati podatke iz prvih trinaest knjiga Vendi- tiones Cancellariae, od sveska 1 (1352.-1361.) do sveska 13 (1451.-1454.). ${ }^{2}$ Ukupan broj kupoprodajnih dokumenata u navedenome razdoblju dostiže brojku od 3272, od čega se trećina odnosi na prodaje nekretnina unutar dubrovačkih zidina. Preciznije, govorimo o 1147 kupoprodaja na kojima se temelji ovaj rad. Zabilježene su i prodaje kuća u ostalim naseljima Republike, prije svega u Stonu, ali i na otocima. Predmeti prodaja raznovrsniji su u četrnaestome stoljeću kada svesci sadržavaju i zapise o prodaji brodova te trgovanju robljem. Ipak, predmet većine prodaja - kako u četrnaestom, tako i u petnaestom stoljeću - jesu tereni, vinogradi i zemljišta u dubrovačkoj astareji (sl. 1.).

Početkom dvadesetog stoljeća Lujo Vojnović proučavao je regeste prodaja nekretnina unutar zidina koje je, prema svescima Venditiones Cancellariae za razdoblje između 1522. i 1667. godine, sastavio Mato Bučinić (Matteo de Buchia). ${ }^{3}$ Pri tome je njegov primarni interes bio »topografski«, s naglaskom na imenima dubrovačkih ulica i lokaliteta. ${ }^{4}$ Osim toga, Vojnović je naglasio da se »mnoge još stvari mogu saznati po ovom na oku suhoparnom spisku«, ukazavši na nekoliko polja istraživanja: "privatnopravni život, ekonomsko stanje i imena stanovnika«.5 I prije Vojnovića, u drugoj polovini devetnaestoga stoljeća, Šime Ljubić istraživao je slične popise toponima teritorija 


\begin{tabular}{|l|c|c|}
\hline Predmet prodaje & $\mathbf{1 3 5 2 . - 1 3 8 6}$ & $\mathbf{1 4 1 7 . - 1 4 5 4 .}$ \\
\hline Zemljišta i posjedi & 487 & 904 \\
\hline Kuće i tereni unutar zidina & 622 & 535 \\
\hline Kuće izvan zidina & 30 & 53 \\
\hline Ostalo (dote, prodaja brodova, robova) & 632 & 19 \\
\hline Ukupno & $\mathbf{1 7 7 1}$ & $\mathbf{1 5 0 1}$ \\
\hline
\end{tabular}

1. Predmeti prodajā u prvih trinaest knjiga serije Venditiones Cancellariae 1352.-1454., sv. 1-13

An overview of sales from the first thirteen books of the Venditiones Cancellariae series 1352-1454, vol. 1-13

dubrovačke komune, na koje je naišao istražujući rukopise iz carske dvorske knjižnice u Beču. ${ }^{6} \mathrm{U}$ središtu Ljubićeva zanimanja bilo je "poznavanje ondašnje topografičke slike dubrovačke obćine«, prilikom čega je istaknuo da bi povjesničari iz podataka koji se u tim vrelima nalaze "mogli nabrati krasnih cvietaka za svoje nauke «. ${ }^{7}$ Unatoč ovim ranim istraživanjima, Venditiones Cancellariae, premda u mnogočemu najrelevantniji izvor za produbljivanje navedenih istraživačkih pitanja, nisu privukli značajnu pozornost.

Početkom dvadesetog stoljeća Josip Gelčić je sveske razdijelio u dvije podserije: Vendite Cancellarie (XXXI. a) i Proclamationes venditionum Cancellariae (XXXI. b). ${ }^{8}$ Međutim, u njegovu se katalogu dubrovačkog arhiva, koji i danas služi kao temeljno pomagalo istraživačima, zamjećuje pauza od pune 122 godine između posljednje knjige prve podserije (1386.) i prve knjige druge podserije (1508.). Drugim riječima, ondje se ne spominju knjige iz petnaestog stoljeća, što je primarni razlog zašto se za tim svescima nije češće posezalo. Nadalje, nužno je napomenuti kako je Gelčićeva podjela građe tek djelomično točna, što će pokazati analiza kupoprodajnih zabilježbi koja slijedi. ${ }^{9}$ Dakle, osim prikaza sadržaja dokumenata, osnovni ciljevi ovoga rada su predstaviti izvor i smjestiti ga u kontekst zakonskih odredbi o trgovanju nekretninama u Dubrovniku kasnog srednjeg vijeka, te istaknuti njegovu važnost za proučavanje onih aspekata dubrovačke prošlosti koji se odnose na prostor grada i vlasništvo.

\section{Venditiones Cancellariae: pravna podloga i sadržaj}

Valja prije svega istaknuti da zapisi kupoprodajnih transakcija između 1352. i 1454. godine nisu cjelovito sačuvani: posljednja upisana prodaja u četvrtoj knjizi datira iz 1386. ., dok sljedeća, peta knjiga, započinje 1417. godinom. Za sada nije poznato je li dokumentacija za razdoblje koje nedostaje izgubljena ili je treba potražiti kao sekundarno pridodanu drugim arhivskim cjelinama. ${ }^{10} \mathrm{Da}$ je to mogući scenarij, pokazuje dvadeset osma knjiga serije Diversa Cancellariae, koja se gotovo isključivo sastoji od kupoprodajnih dokumenata koji datiraju između 1388. i 1395. godine, dok tek manji dio upisa na kraju knjige odgovara nazivu serije. Jednako tako, šesta knjiga serije Debita notariae, kako je primijetio Ignacij Voje, sadrži 65 listova sa zapisima o prodaji kuća između 1352. i 1365. godine, čime ti dokumenti sadržajno također pripadaju Venditiones. ${ }^{11} \mathrm{U}$ daljnjim se istraživanjima prodaja nekretnina stoga nužno moraju uključiti i ti podaci.
Uz to što je građa koja se odnosi na starije razdoblje necjelovita, nužno je naglasiti da nije homogena ni sadržajem. Premda se svi dokumenti odnose na prodaje (i tek u neznatnom dijelu na najmove), sadržaj pojedinih svezaka se razlikuje. Tako neke od najranijih knjiga - prva (1352.-1361.), treća (1371.-1382.) i četvrta (1382.-1386.) - sadrže proklamacije (gridae, cridae), zabilježene u formi u kojoj su se javno čitale. Izvikivao ih je općinski glasnik (preco comunis), obznanjujući imena prodavatelja i kupaca, predmet prodaje, vlasnike susjednih parcela i ostale granice te cijenu nekretnine. Tekst tih prijašnjih dokumenata završava kancelarijskim formulama koje pronalazimo još u kupoprodajnim dokumentima iz trinaestog stoljeća, što potvrđuje da se način zapisivanja prodaja nije mijenjao. ${ }^{12}$

Druga je knjiga slučaj za sebe s obzirom na to da zapisi formom odstupaju od ostalih: sažetiji su, po nekoliko ih je upisano na istome listu te ne započinju uobičajenom formulom proklamacije. U tim dokumentima prodavatelji u prvome licu potvrđuju (confiteor) transakciju navodeći već spomenute elemente kupoprodajnih ugovora. U završnom su dijelu ove knjige zapisane nekretnine koje se primaju kao mirazi (formula pro perchivio uxoris mee), što je također razlika u odnosu na ostale obrađene knjige. ${ }^{13}$ Zaključno, period koji pokrivaju druga (1365.-1379.) i treća knjiga (1371.-1382.) djelomično se preklapa, što nije slučaj s ostalim analiziranim knjigama, i što dokazuje da današnji svesci tek djelomično odgovaraju izvornoj strukturi.

Općenito gledajući, upisi u svescima iz prve polovine petnaestog stoljeća (sv. 5 do sv. 13) jesu složeniji, te je njihovu strukturu moguće podijeliti na tri dijela (sl. 2.). Uvodni se tekst može okarakterizirati kao zapis prodaje: prvo se navode imena prodavatelja, nakon čega slijedi definiranje predmeta prodaje i njegovih granica te se, naposljetku, upisuje ime kupca. Prodaje se izriču s nekoliko dispozitivnih glagola: dedo (dajem), vendo (prodajem) i trado (predajem), koji su zamjenjivi te se uobičajeno navode skupno, tako da formula dispozicije u perfektu trećeg lica jednine glasi dedit, vendidit et tradidit. Zatim slijedi ugovaranje tijeka isplate, tj. roka do kojega će transakcija biti privedena kraju i visine obroka u kojima će iznos biti isplaćen. Uz to se zapisuju i uvjeti prodaje, najčešće reguliranje prava na mogućnost uživanja nekretnine do smrti prodavatelja.

Uz kupoprodaje među privatnim osobama, učestali je oblik prodaje bio putem javne dražbe (ad pubblicum incantum). U ovim je slučajevima, kada je nekretninu prodavao sud ili općina, ona bila prodavana ponuđaču najvišeg iznosa (tamquam plus offerenti). ${ }^{14}$ Manji je dio transakcija ostvaren tzv. "tihim dražbama" (ad incantum tacitum ili ad pubblicum incantum factum tacita voce). Ovaj, još uvijek slabo istraženi oblik prodaje, zabilježen je i u Liber viridis, a o čemu se zapravo radilo saznajemo iz glave 158. Lastovskog statuta. Naime, ondje se kao krivično djelo navodi »običaj da se zemljišta prodaju potajno ili da se, na štetu međašnika, prikrivaju darovanjima« te se određuje da se »tihe prodaje« mogu provesti isključivo u četiri slučaja: između oca i sina, braće, prvih rođaka i osoba za koje je »općepoznato da su darovateljevi dobročinitelji ${ }^{15}{ }^{15}$ Jesu li i u Dubrovniku vrijedila 


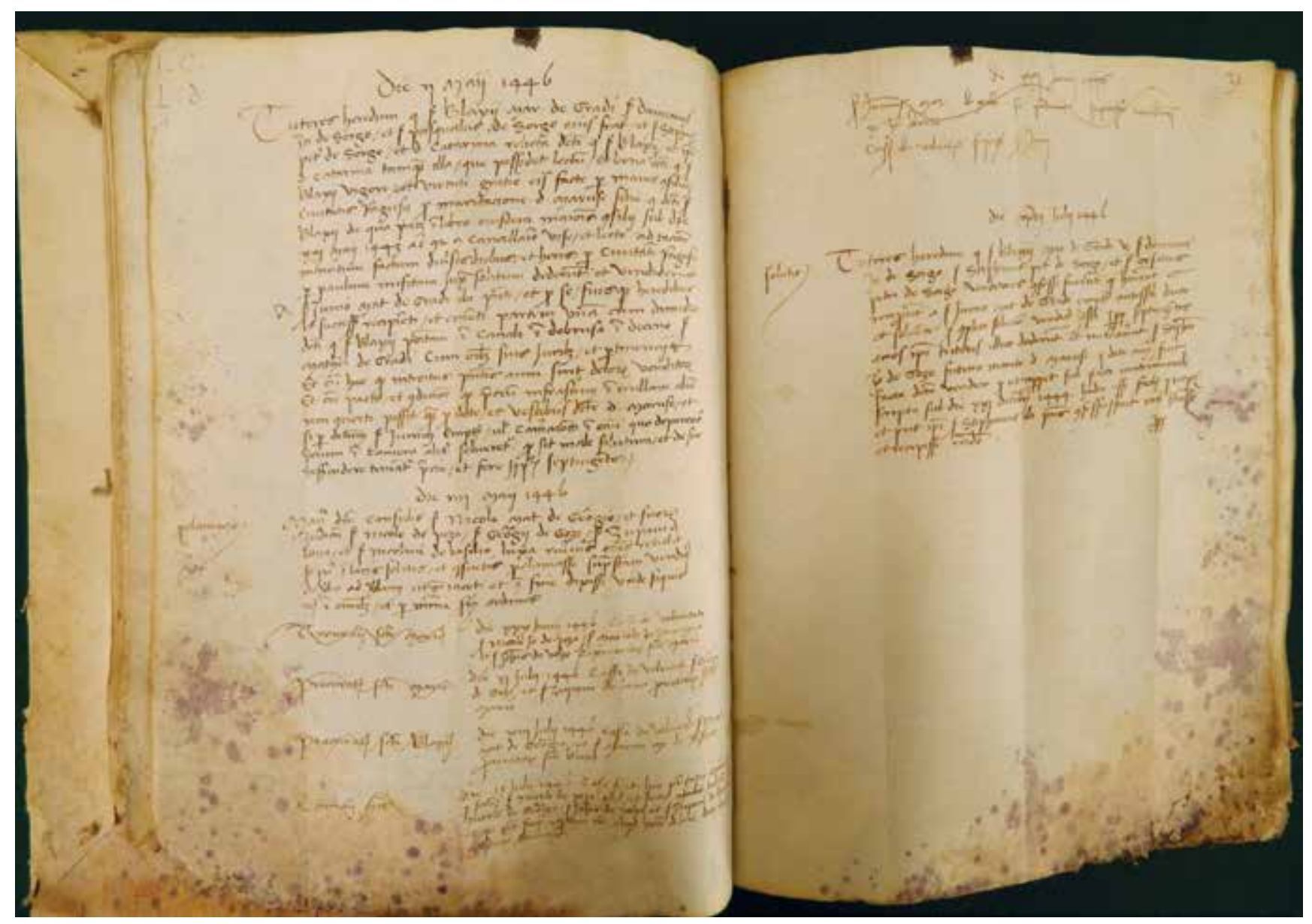

2. Karakteristični dijelovi dokumenata serije Venditiones Cancellariae (foto: A. Plosnić Škarić)

Characteristic elements of documents from the Venditiones Cancellariae series

ista pravila za sada nije dovoljno poznato, ali iz nekih drugih izvora saznajemo da su »tihe prodaje« bivale registrirane u zasebnim knjigama. ${ }^{16}$

Nakon uvodnog dijela kupoprodaja, slijedi zapis o izvršenoj proklamaciji (proclamatio) opisane prodaje, datiran od nekoliko tjedana do nekoliko mjeseci poslije datuma zapisa prodaje. Tu dolazimo do ključne razlike između zabilježbi prodaja u knjigama četrnaestoga i petnaestog stoljeća: dok je u starijim svescima zapis o proklamaciji ujedno i (prva) zabilježba prodaje, u novijim se imena prodavatelja i kupca, naziv nekretnine i cijena zapisuju prije same proklamacije, kako to pokazuju dokumenti koji su kao karakteristični doneseni u prilogu ovog teksta - prodaja kamene kuće majstora graditelja Ivana iz Vienne, u seksteriju sv. Nikole, 1386. godine (Prilog 1) te kasnija prodaja kuće zlatara Dobre Pribisalića u seksteriju sv. Vlaha (Prilog 2).

Zapis o proklamaciji, prisutan u oba opisana načina registriranja kupoprodaja, značio je da je prodaja javno oglašena prema važećim propisima. Bilo je, naime, nužno osigurati da sve potencijalno zainteresirane strane - u prvom redu srodnici i susjedi prodavatelja (koji su imali pravo prvokupa), a potom i njegovi vjerovnici - mogu doći do informacije o prodaji, čime su se izbjegavali eventualni kasniji sporovi.
Statutom je bio određen rok za očitovanje onih koji su iz bilo kojeg od navedenih razloga polagali pravo na nekretninu, uključujući i slučajeve njihova izbivanja iz Dubrovnika. Godine 1320. određen im je rok od dvije godine unutar kojih su bili dužni "predočiti, pokrenuti i ostvariti svoje pravo protiv kupca na prodanu stvar ${ }^{17}{ }^{17}$ dok je kupcima bilo zabranjeno napustiti Dubrovnik ne ovlaste li prethodno opunomoćenika (prokuratora) koji će ih u prodaji zastupati. ${ }^{18}$

Iza formule proklamacije in locis solitis et consuetis kriju se mjesta na kojima su se one izvikivale, u pravilu na frekventnim gradskim točkama, ${ }^{19}$ kojih je u Dubrovniku bilo nekoliko. U Statutu je dodana odredba da se svaka prodaja nekretnine mora oglašavati tri mjeseca na ploči postavljenoj ispred gradske lože. ${ }^{20}$ Krajem četrnaestog stoljeća, po završetku gradnje nove crkve sv. Vlaha, jedno od uobičajenih mjesta proklamacija postaje crkva gradskoga zaštitnika, što jasno navode i pojedini kupoprodajni dokumenti. ${ }^{21}$ Tijekom prve polovine petnaestoga stoljeća, međutim, dolazi do zabrane njihova oglašavanja u crkvama, kako je zabilježeno u Liber viridis, te se od tada proklamacije zabilježene u Venditiones Cancellariae izvikuju u luži pred crkvom sv. Vlaha, ${ }^{22}$ ali i u nekadašnjoj velikoj, gradskoj loži, smještenoj ispred Kneževe palače $^{23}$ 
Naposljetku, treći se dio zapisa odnosi na iskazivanje zanimanja stranaka zainteresiranih za objavljenu prodaju, što je ujedno i najsloženiji segment dokumenata ove arhivske cjeline. Javljanje, doslovno predstavljanje (presentatio) interesenata, zapisivano je nakon objavljene proklamacije, obično u tjednima i mjesecima, a ponekad čak i godinama koje su slijedile. Brojni naknadni upisi često prekrivaju cijeli list, ispunjajući i margine. U osnovi, radilo se o dužem procesu čiji je završetak ujedno značio da je prodaja mogla stupiti na snagu, pošto su potraživanja zainteresiranih bila podmirena. Zaključenje posla prodaje, tj. podmirivanje iznosa kupnje $u$ cijelosti, navodi se na samom kraju dokumenta, u pravilu pod oznakom solutio.

Tijekom petnaestog stoljeća notari su bili dužni unaprijed uza svaku prodaju u registru upisivati, kao potencijalno zainteresirane, sljedeće pravne osobe: rizničare i prokuratore katedrale sv. Marije Velike, prokuratore crkve sv. Vlaha te općinske blagajnike. Godine 1411. donesena je odluka prema kojoj se iza svake zabilježbe proklamirane prodaje, uz navedene institucije moraju upisati i prokuratori općinskog hospitala. ${ }^{24}$ Međutim, $u$ analiziranim se dokumentima oni ne javljaju, te je moguće da se ta odluka provodila u godinama neposredno nakon 1411., ali je praksa napuštena do 1417. godine, otkada datira najstariji sačuvan zapis o prodaji iz petnaestoga stoljeća. Nakon spomenutih ustanova bilježena su imena susjeda i rođaka prodavatelja koji su imali pravo prvokupa. ${ }^{25}$ Ipak, taj važni segment prodaja tek čeka podrobniju analizu, dok su za teme kojima se bavi ovaj rad ključni podaci zapisani u prvome dijelu dokumenta, o čemu će biti riječ u nastavku teksta.

\section{Predmeti prodaje}

Građa poput Venditiones Cancellariae može se analizirati na više načina, no kako je cilj ovog teksta pružiti panoramski pogled na sadržaj svezaka, kao prvi se korak logično nameće kvantitativna obrada podataka. Statistička analiza zapisa o prodajama omogućuje usporedbu podataka tijekom razmatranog perioda ${ }^{26} \mathrm{i}$ razmatranje njihove važnosti za poznavanje administrativne podjele gradskog prostora na seksterije te urbane topografije Dubrovnika. Rezultati analize bit će predstavljeni grafovima.

Sa stajališta analize predmeta prodaja posebno je, kada je riječ o kućama u gradu, rječita usporedba vrsta prodavanih nekretnina tijekom druge polovine četrnaestog stoljeća, vremena odvijanja ključnih promjene u izgledu grada zbog zamjenjivanja drvenih kuća kamenima. ${ }^{27}$ Taj postupni proces prijelaza od pretežno drvenog u cijelosti kameni grad uočljiv je i u zastupljenosti pojedinih vrsta prodavanih kuća tijekom četrnaestog i petnaestog stoljeća: izjednačeni udio drvenih $i$ kamenih kuća u četrnaestom stoljeću, u idućem će se stoljeću okrenuti u korist kamenih, s tek jednom zabilježenom prodajom drvene kuće (sl. 3.). Među ostalim tipovima nekretnina pronalaze se kuće od suhomeđine (maceria, mazeria) te djelomično zidane kuće, ali u znatno manjem postotku.

Osim navođenja osnovnoga gradivnog materijala, nekretnine se u zapisima ne opisuju; izostaju podaci o veličini,

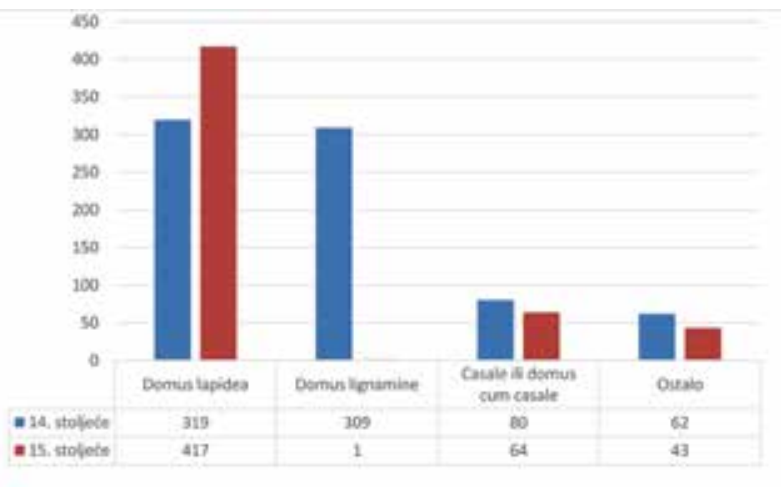

3. Usporedba prodavanih nekretnina u 14. i 15. st. (prema Venditiones Cancellariae, sv. 1-13 i Diversa Cancellariae, sv. 28)

Comparison of properties sold in the $14^{\text {th }}$ and $15^{\text {th }}$ centuries (according to Venditiones Cancellariae, vol. 1-13 and Diversa Cancellariae, vol. 28)

katnosti ili unutrašnjoj opremi. Iz toga se nameće zaključak da se dodatne karakteristike kuća, navedene vrlo rijetko, bilježe jedino u slučajevima kada se radilo o nestandardnim elementima nekretnina koji su očito signalizirali veću tržišnu vrijednost. Među tim se elementima nalaze vanjska stubišta, trijemovi, bunari, gajfumi i peći. Mjere parcela, a time i kvadrature prizemlja, još su rjeđe zapisivane. Štoviše, one se navode samo kada se kuća nije prodavala u cijelosti, pa je navođenje mjera, iskazanih dubrovačkim laktima, bilo u službi preciznijeg definiranja predmeta prodaje. ${ }^{28}$ Nadalje, posebni termini vezani uz kuće rijetko se spominju, a među njima se ističe domus magna. Primjerice, godine 1423. ser Mihovil pokojnog Šimuna Restića za simbolični iznos od jednog perpera prodaje sinu Andriji »veliku kuću (domus magna) u kojoj obitava ${ }^{29} \mathrm{~S}$ obzirom na to da se radi o plemićkoj obitelji u kojoj je nasljedstvo teklo uobičajenim obrascem de herede in herede, kao i činjenicu da je Mihovil stanovao u spomenutoj kući, domus magna neprijeporno označava glavnu obiteljsku kuću, tj. obiteljski »statusni simbol «. ${ }^{30}$

Nakon kuća, druga najbrojnija vrsta nekretnina naziva se casale, što u sačuvanim kupoprodajnim ugovorima može (u urbanom kontekstu) imati raznolika značenja, uključujući građevinske čestice, ali i matične obiteljske kuće. ${ }^{31} \mathrm{U}$ dokumentima četrnaestoga stoljeća, međutim, tako se označavaju i ruralni sklopovi, uključujući gradilišta, ali i cjeline sastavljene od manjih objekata, a nazivi domus i casale nerijetko se u istom dokumentu rabe kao sinonimi. ${ }^{32}$ Može se, nadalje, raditi o slobodnoj građevinskoj čestici zbog čega se casale dovodi u vezu s terminom terrenum. ${ }^{33}$ Indikativno je, međutim, da se pojedini casale prodaju "sa kamenjem, žbukom, pijeskom i zemljom koja se ondje nalazila «, ${ }^{34}$ što ukazuje na to da se radilo o građevinskim česticama namijenjenim podizanju kamenih kuća ili pak nedovršenim građevinama.

Osim toga, pojedini zapisi svjedoče da je casale mogao biti i cjelina sastavljena od više povezanih objekata različitih volumena, organiziranih oko zajedničkoga nenatkrivenog prostora (unutarnjeg dvorišta, atrija). ${ }^{35} \mathrm{Na}$ to ukazuje sintagma sex casalia in unum, zabilježena u seksteriju Sv. Vlaha, ${ }^{36}$ ili prodaja jedne kuće in casale u seksteriju sv. Petra. ${ }^{37} \mathrm{U}$ 


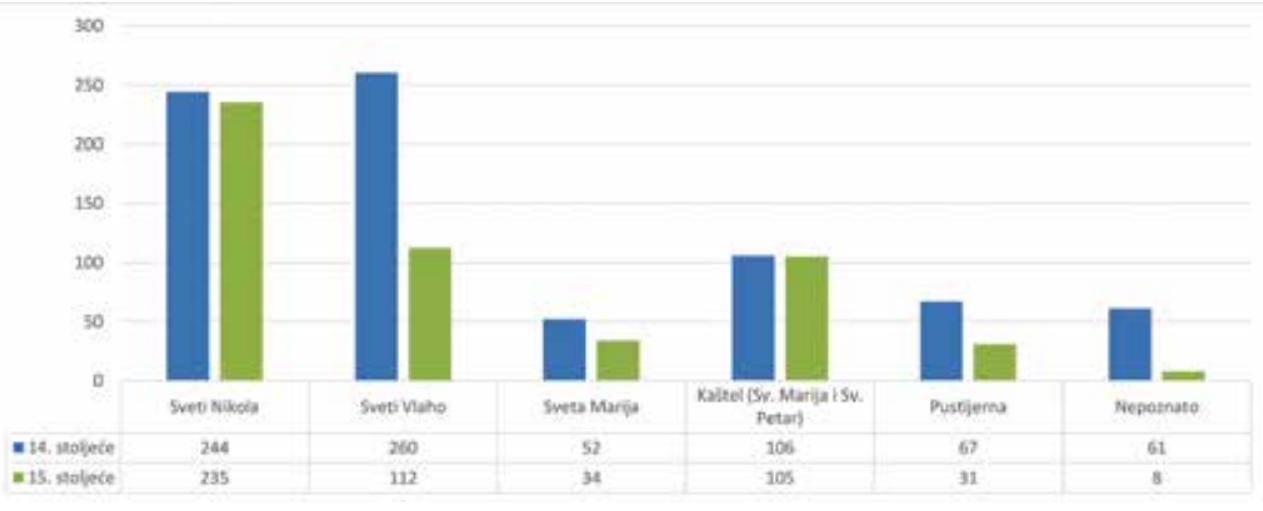

4. Raspored oglašenih prodaja po dubrovačkim seksterijima (usporedba 14. i 15. st.)

Announced sales according to the sexteria (comparison between the $14^{\text {th }}$ and $15^{\text {th }}$ centuries)

ovom svjetlu valja navesti da su brojni i slučajevi prodaja kuća s casalima koji su se nalazili pored njih, pri čemu se vrlo vjerojatno radi o nekretninama s nekim tipom dvorišta ili okućnicom, i time o reprezentativnoj nekretnini. Treba istaknuti i da je najveća, ujedno i najskuplja nekretnina prodana u razmatranome periodu bila upravo casale. Velikih dimenzija, u tlocrtu pravokutnika sa stranicama od devet i pol sežanja (preko devetnaest metara) u smjeru istok-zapad te oko tri i pol sežnja na potezu sjever-jug (oko sedam metara), casale u seksteriju Sv. Vlaha je 1423. godine prodan bogatom trgovcu Antoju Butkovu za cijenu od 3000 perpera, da bi u ponovnoj prodaji 1425. postigao cijenu od čak 8000 perpera. ${ }^{38}$

\section{Prostor Grada: seksteriji, susjedstva i ulice}

Uz analizu podataka prema tipu prodavane nekretnine, sljedeći je korak analiza ostvarenih prodaja po gradskim seksterijima. Tijekom druge polovine četrnaestoga stoljeća kućama se najviše trgovalo na području nekadašnjeg predgrađa, u seksterijima sv. Vlaha i sv. Nikole; ukupan je broj transakcija u seksteriju sv. Vlaha premašivao, doduše neznatno, onaj u (znatno prostranijem) seksteriju sv. Nikole, što je nastavak trenda iz prošlog stoljeća. ${ }^{39}$ Situacija će biti obrnuta u petnaestom stoljeću, kada se gotovo polovina svih prodavanih nekretnina unutar grada nalazila sjeverno od Place, a njihov je broj dvostruko nadilazio broj prodaja u seksteriju sv. Vlaha. ${ }^{40}$ Najstariji dio grada, tj. područje seksterija Kaštel (Sv. Marije od Kaštela) i Sv. Petra, bilježi razmjerno velik udio u prodajama, pogotovo uzmemo li u obzir da su u odnosu na seksterije sv. Vlaha i sv. Nikole imali znatno manje površine. Broj prodavanih nekretnina s nepoznatom lokacijom, iskazano generičkom formulom intra suos confines, u petnaestom je stoljeću, za razliku od četrnaestog, neznatan, što omogućuje precizniju ubikaciju prodavanih kuća (sl. 4.).

Razvrstavanje nekretnina prema seksterijima nedvojbeno otvara put nizu istraživačkih pitanja, uključujući, primjerice, usporedbu cijena i lokacija kuća te smještaja i društvenog statusa njihovih vlasnika. U obzir pritom treba uzeti činjenicu da nam još uvijek nisu sasvim pouzdano poznate sve granice između pojedinih seksterija koje su, barem sudeći prema kupoprodajnim dokumentima, bile fluidne. ${ }^{41}$ Tako, primjerice, zapisi o prodajama kuća »u Kaštelu « obuhvaćaju, dakako, one u seksteriju Sv. Marije (od Kaštela), ali i u seksteriju Sv. Petra, kojem se također često pridjeva naziv »od Kaštela «. ${ }^{42}$ Postoje, nadalje, slučajevi da se riječ »seksterij« ne rabi u svome prvotnom značenju (kao jedan od šest dijelova grada prema službenoj administrativnoj podjeli), nego kao naziv za uži gradski predio, primjerice, u blizini neke crkve, kao što je to često bivalo s područjem oko crkve sv. Stjepana, koje se naziva seksterijem Sv. Stjepana. ${ }^{43}$ Budući da se Sv. Stjepan nalazi na samoj granici seksterija sv. Petra i Pustijerne, nemoguće je u takvim slučajevima sa sigurnošću odrediti u kojem se od njih nekretnina nalazila. Na sličan je način teško utvrditi granice seksterija sv. Marije Velike, dijela koji se najvjerojatnije odnosio na područje neposredno oko katedralne crkve. ${ }^{44}$ Međutim, pronalaze se i izdvojeni slučajevi, poput navođenja nekretnine pored crkve sv. Jelene (sv. Križa), koja bi se, smještena gotovo uza sami rub južnog poteza zidina, trebala nalaziti na razmeđu seksterija sv. Petra i Pustijerne, ali je nekoliko puta navedena u seksteriju Sv. Marije. ${ }^{45}$ Tako je slučaj zamjenjivanja južnih gradskih seksterija identičan onome nizinskim, Sv. Marije i Sv. Vlaha. ${ }^{46}$

Činjenica je, dakle, da kupoprodajni dokumenti nisu prvorazredni izvor za utvrđivanje preciznih granica seksterija. Ipak, prenošenjem podataka u zapisima na plan grada moguće je o tome steći nove uvide, primjerice za seksterij Sv. Vlaha, za čije su granice istraživači suglasni da ih nije lako odrediti. ${ }^{47}$ Tako je prema analiziranim zapisima o prodajama sjeverna granica seksterija bila južna strana Place, i to u svojoj punoj duljini, od samostana klarisa, do crkve gradskoga zaštitnika na zapadnome kraju. Iako prema Beritićevoj interpretaciji kasnosrednjovjekovna crkva sv. Vlaha, građena tijekom druge polovine četrnaestog stoljeća, nije pripadala seksteriju istoga naziva, ${ }^{48}$ zapisi u proučavanim knjigama Venditiones Cancellariae potvrđuju kako se ovaj seksterij prostirao 
upravo do te crkve. Naime, 1357. godine prodaje se polovica kamene kuće u seksteriju sv. Vlaha koja sa svoje zapadne strane graniči cum platea comunis iuxta logiam novam, ${ }^{49} \mathrm{tj}$. kod luže koja se tada još bila gradila. Jugoistočna je granica seksterija bila predio iza samostana klarisa, uključujući i nekadašnje crkve sv. Martina i sv. Marka. ${ }^{50}$ Iz registriranih prodaja za sada nije moguće ustanoviti niti granice prema južnijim seksterijima, sv. Petra i sv. Marije Velike, poglavito s potonjim, jer se za crkvu sv. Vida u Pracatovoj ulici, u blizini koje se pretpostavlja razgraničenje, naizmjence bilježi da se nalazi u oba ta seksterija.

Uz imena seksterija, u pojedinim su zapisima o prodajama navedeni i nazivi užih prostornih jedinica, poput "susjedstava (contrada, vicinia), a katkad i ulica (ruga, strata, via, calle, uliza). Naziv Garište, koji i danas nosi jedna od dubrovačkih ulica, označavao je opožareni teren i odnosio se na dio seksterija sv. Vlaha zapadno od Široke ulice, u vlasništvu nadbiskupije. Na njemu smještene kuće ubiciraju se terminom in Gariste, ili in contrata appellata Brusa (od glagola bruciare, spaliti). ${ }^{51}$ Postoji još toponima koji su i danas u upotrebi, uključujući spomenutu Široku ulicu (strata larga, via larga ili ruga larga), ${ }^{52}$ Prijeki (Priechi put) ${ }^{53}$ te Zlatarska i Kovačka ulica. Termin »ulica« u zabilježbama se prodaja odnosi na javnu ulicu (via comunis) koja se navodi bezimena, tek kao međaš nekretnine $\mathrm{u}$ prodaji. ${ }^{54}$ Glavna gradska ulica, Stradun, naziva se platea communis ili skraćeno platea. Primjerice, zabilježena je prodaja kuće in platea comunis, prope ecclesiam Sancti Francisci, ${ }^{55}$ te kuće super plateam comunis versus portam Pillarum. ${ }^{56}$ Premda se takve uže prostorne odrednice javljaju rijetko, one nude nove podatke o uvriježenom nazivlju mikrolokacija onodobnog Dubrovnika, koje se ne javljaju u drugim suvremenim izvorima.

Dio susjedstava i ulica očekivano se označava prema obližnjim crkvama kao istaknutim prostornim markerima, ${ }^{57} \mathrm{dok}$ dio nosi naziv obitelji ili pojedinaca. Upravo se ti slučajevi koliko god bili rijetki - čine posebno važnima jer svjedoče o istaknutom društvenom položaju pojedinaca, a istovremeno mogu ukazivati na neuobičajenu veličinu njihovih stambenih jedinica. $U$ toj se skupini toponima ističe Koradinova ulica u seksteriju sv. Vlaha (u izvorima ruga Corradini, vicinio Corradini ili de Coradino).$^{58} \mathrm{U}$ istom su seksteriju zabilježene i ulice Dživka Kabužića, ${ }^{59}$ trgovca Milgosta ${ }^{60}$ Junija Đurđevića $^{61}$ te »ulica u kojoj živi nosač Lukša «. ${ }^{62} \mathrm{U}$ seksteriju Sv. Marije zabilježena je ulica de Slavzichi ${ }^{63}$ a u Kaštelu vicinium illorum de Vitanis ${ }^{64}$ te ulice Gavže Pucića ${ }^{65}$ i Dabiživa Latinice. ${ }^{66}$ Potonja se ulica 1440 . godine navodi prema imućnom trgovcu rudama u Bosni, čiji su sinovi Martol i Vlaho samo nekoliko godina prije u seksteriju de San Piero o di Sancta Maria kupili tri kuće, casale i dvorište (cortivo). ${ }^{67}$

\section{Tereni i vlasnička topografija}

Na pitanje urbane toponimije nadovezuje se ono vlasničke topografije. Iz svega dosada rečenoga jasno je kako se nalazimo pred prvorazrednim izvorom za proučavanje vlasničke, a posredno i socijalne topografije kasnosrednjovjekovnog
Dubrovnika. ${ }^{68}$ Naime, osim starih i novih vlasnika nekretnina, navedeni su i vlasnici graničnih čestica (prema stranama svijeta ili smjeru puhanja vjetrova) što znatno povećava broj poznatih vlasnika kuća. Daljnja vrijednost izvora leži u činjenici da su zapisani i vlasnici zemljišta (terrenum ili territorium) na kojima su kuće bile podignute. Naime, posjedovanje nekretnine na tuđem zemljištu zahtijevalo je plaćanje najma fizičkim ili pravnim osobama koje su teren posjedovale. Teret (nazivan angaridium ili, rjeđe, teraticum) bio je isplaćivan u novcu (u izvoru iskazan u perperima i/ili grošima). Zemljišta su se mogla prodavati i zasebno, bez kuća koje su na njima bile sagrađene. Primjerice, Ivan Markov je 1429. godine kupio territorium u seksteriju Sv. Vlaha na kojemu su bile sagrađene dvije kamene kuće drvodjelaca Gojaka i Ivana; ta su se dvojica obvezala nastaviti plaćati teret novome vlasniku. ${ }^{69}$

U prva dva sveska podaci o iznosima najma ili teretima uglavnom izostaju, što će se promijeniti 1372 . godine kada je u dodatku 34. glave pete knjige Statuta propisano da $» u$ naznačenoj kupoprodaji mora biti sadržano na kojem se zemljištu nalazi dotična kuća i koliko se najma plaća «. ${ }^{70}$ Upravo oko te godine, što korespondira s početkom treće knjige Venditiones Cancellariae, počinje se češće zapisivati kome se teret plaća, ali se unatoč tome radi o malom postotku ukupnih prodaja. Iz tog je razloga ovdje predstavljena analiza ograničena na prodaje iz petnaestoga stoljeća, kada se angaridium redovito zapisuje. Godišnji najam za korištenje zemljišta se za najveći broj kuća plaćao komuni stoga što je većina kuća bila podignuta na općinskome zemljištu, posebice u seksteriju sv. Nikole, koji prednjači u ukupnom broju prodaja. Budući da oko jedne četvrtine prodaja otpada na seksterij sv. Vlaha, ne začuđuje velik broj kuća čiji su korisnici rentu za korištenje zemljišta plaćali nadbiskupiji (ukupno 69 nekretnina). Podaci za cijeli grad otkrivaju da manji broj nekretnina, svega 23 , teret plaća fizičkim osobama koje su posjedovale zemljišta, ukupno 30 kuća teret plaća institucijama katedralne crkve (rizničari, kanonički kapitul i prokuratori), dok iznos gradskim crkvama i samostanima daju vlasnici 46 nekretnina. U jednoj petini slučajeva nije navedeno je li postojala obaveza plaćanja tereta, a u dijelu prodaja te obveze zasigurno nije bilo (formula (domus) libera et franca ab omni angaridio) (sl. 5).

U kontekstu istraživanja vlasničke topografije, posebnu važnost imaju zemljišta privatnih vlasnika, poput onoga koje je 1429. godine, kako je spomenuto, kupio Ivan Markov. Važno je istaknuti kako se većina takvih terena u zapisima o prodajama četrnaestoga i petnaestog stoljeća nazivala imenima svojih vlasnika iz prijašnjih stoljeća. Primjerice, za desetak se kuća u seksteriju Sv. Nikole bilježi da se nalaze super terreno illorum de Svieri, usprkos činjenici da je prema recentnim genealoškim istraživanjima, ta obitelj (Sfieri, Suiri, Zvieri) izumrla još krajem trinaestog stoljeća, ${ }^{71}$ kada se kao vlasnik terena navodio Ivan Sueri. ${ }^{72}$ Godine 1370 . Veliko vijeće određuje da vlasnici kuća na tom terenu moraju potvrditi (firmari) pravo na građevinsku česticu u slučaju da na njoj namjeravaju sagraditi kuće, zidane ili od suhozida. ${ }^{73}$ Povod ovoj odluci gradskih vlasti bio je razorni požar, čije su posljedice zabilježene i u Venditiones Cancellariae, te je u godinama nakon požara ostvareno nekoliko prodaja prava 


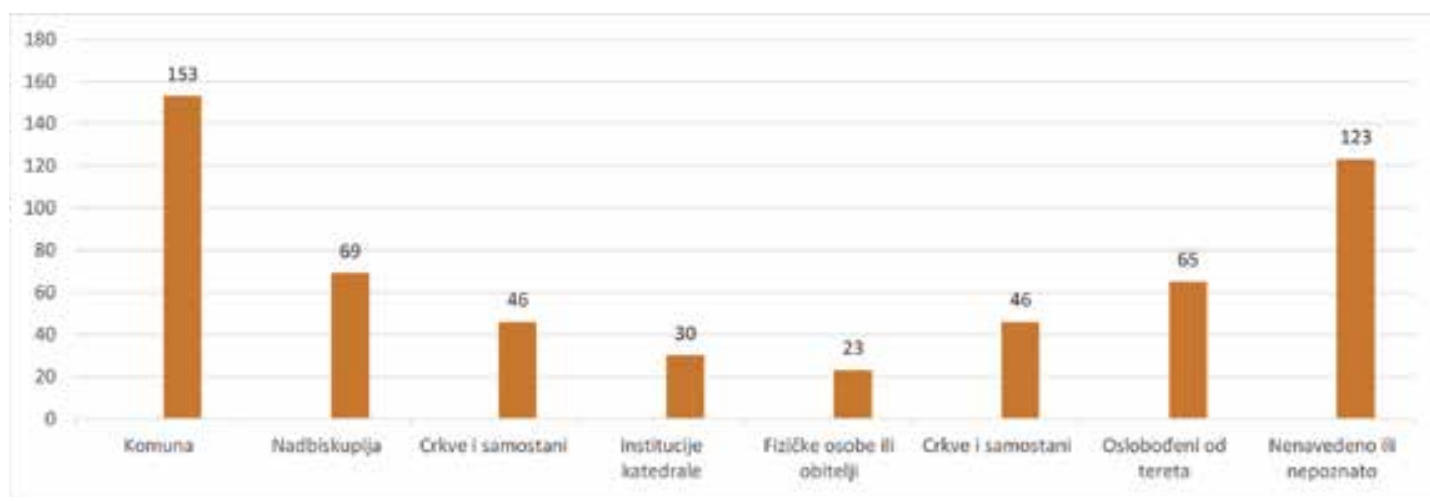

5. Raspored plaćanja tereta (angaridium ili teraticum) u prvoj polovici 15. st.

Property fee (angaridium or teraticum) in the first half of the $15^{\text {th }}$ century

(jus terreni) na opožareno zemljište gdje su se bile nalazile uništene drvene kuće. ${ }^{74}$ Vlasnici tih kuća su teret plaćali komuni, dok je u jednom slučaju navedeno da je iznos išao obitelji Svieri, pri čemu se vrlo vjerojatno radi o pogrešci, jer je ta obitelj tada već davno bila izumrla. ${ }^{75}$

Taj izdvojeni primjer tek je jedan od mnogih koji ukazuju na složenost problematike izučavanja vlasništva nad terenima u nekim dubrovačkim seksterijima. $S$ druge strane, sama činjenica da se vlasništvo nad zemljištima u trinaestome stoljeću navodi i u petnaestom, unatoč tome što obitelj koja je polagala pravo na njega više ne postoji, upućuje na dugo zadržavanje nazivlja pojedinih terena. Drugim riječima, analizom podataka o terenima iz Venditiones Cancellariae, premda se radi o drugoj polovici četrnaestog i prvoj polovici petnaestog stoljeća, u budućim će istraživanjima možda biti moguće rasvijetliti i situaciju u trinaestome stoljeću, koja je puno slabije dokumentirana. Usporedbom podataka o lokacijama nekretnina koje su se nalazile na pojedinom terenu, bit će moguće ubicirati njihove granice, što je također jedan od ciljeva istraživača koji su recentno razmatrali ova pitanja. ${ }^{76}$

\section{Prilozi}

1.

Majstor graditelj Ivan iz Vienne 1386. godine prodaje svoju kamenu kuću u seksteriju sv. Nikole Stojku Stanislaliću za tisuću perpera.

\section{MCCCLXXXVI die XXIIII februari indictione XV}

Obrad preco comunis de mandato domini rectoris ser Mathei de Georgio et de voluntate partium, cridavit in locis consuetis quod magister Johannes de Viena lapicida vendidit Stoycho Stanislalich unam suam domum lapideam positam Ragusii in sexterio Sancti Nicole, que confinat a parte levantis cum terreno Sancte Marie de Castello, a parte ponentis cum via comunis, a parte montis et cum via comunis, a parte maris cum casali Martini de Georgio cum omnibus iuribus et pertinentiis, et cum angaridio cui subiectum est terrenum

\section{Zaključak}

Cilj ovoga rada bio je predstaviti građu Venditiones Cancellariae iz Državnog arhiva u Dubrovniku i naglasiti njezin potencijal $u$ istraživanjima urbanističkog razvoja i vlasničkih struktura srednjovjekovnoga Grada. Budući da se radi o serijskom izvoru, podaci su ovom prilikom analizirani statistički prema tipu prodavane nekretnine, pripadnosti seksterijima te obvezi plaćanja tereta. Nakon same analize sadržaja izvora, u kojemu su ocrtane njegove glavne karakteristike, prije svega usporedbom kupoprodajnih dokumenata četrnaestog i petnaestog stoljeća, raspravljalo se o terminologiji nekretnina te (ne)stalnosti navođenja pojedinih seksterija, kao i službenom i neslužbenom nazivlju određenih mikrolokacija unutar dubrovačkih zidina. ${ }^{77}$ Vrijedne podatke koje izvor sadrži u budućim bi istraživanjima trebalo povezati s konkretnim prostorom ondašnjeg Dubrovnika, a sljedeći bi korak svakako trebao uključivati kreiranje baze podataka. Jedino tako će se podaci koje krije ova arhivska cjelina moći kontekstualizirati na pravi način.

dicte domus, quod debetur conventui fratrum predicatorum singulis annis yperperorum quinque, pro yperperis mille. Unde si quis et cetera.

Cum hiis pactis et conventionibus scilicet quod dictus Stoychus emptor teneatur dare nunc pro parte solutionis dicte emptionis dicto magistro Johani venditori yperperos quadrigentos et per totum mensis madii proxime venturi yperperos centum, et totum residuum per totum mensis julii. Si domus fuerit perfecta ut promixit dictus venditor (et presentati fuerint depenati. Renunciando). Et si aliquo (!) causa domus predicta (ante finitum tempus in bandictionis cancell.) ab aliquo esset subtracta, tunc ipse magister Johannes per apthay se obligando renuncians promissit reddere et restituere sine termino totum illud quod ipse habuisset dicta de causa. 
Dictus magister Johannes de Viena venditor fuit confessus habuisse a dicto Stoycho emptore pro parte dicte venditionis yperperos quadringentos.

ypp. IIII

Thesaurarii Sancte Marie presentaverunt se dicte vendictioni quia habent dicere supra ipsam. (Cassum de mandato ser Blasii et Stefani thesaurariorum)

Camerarii comunis presentaverunt se dicte vendictioni quia habent dicere supra ipsam. Procuratores Sancte Marie presentaverunt se dicte vendictioni quia habent dicere supra ipsam. (Cassum de mandto dictorum procuratorum ser Jo. de Volço, ser Luce de Bona)

\section{Die XXVI februari}

Martinus de Georgio presentavit se dicte vendicioni quia habet dicere supra ipsam prope confirma (Cassum de voluntate Martoli de Goçe et Nalischi sertoris epitroporum dicti Martini)

Die ultimo februari

Angellus Calçich se presentavit dicte vendicioni quia habet dicere super ipsam (Cassum de voluntate dicti Angeli, VIII aprilis 1391)

Die XIIII junii

Dictus magister Johannes venditor fuit confessus habuisse et recepisse a ser Stephani de Lucari et Ivanno sertore nomine dicti emptoris et de bonis ipsius emptoris yperperis centum.

Die XIII julii

Dictus magister Johannes venditor fuit confessus habuisse a dicto emptore pro parte dicte vendicionis yperperos sexaginta.

ypp. LX

Die ultimo novembris $<13>86$

Dictus magister Johannes venditor fuit confessus habuisse a dicto emptore pro parte dicte vendicionis yperperos quadraginta id est

ypp. XL

MIII ${ }^{\complement}$ LXXXVII die XXII februarii dictus magister Johannes confessit recepisse pro parte solutionis dicte vendicionis a dicto emptore ypp. C.

Die XX aprilis 1387

Dictus magister Johannes confessit recepisse pro parte solutionis dicte vendicionis a dicto emptore ypp. CXXV.

Die XVII junii $<13>87$

Dictus magister Johannes confessit habuisse pro parte solutionis dicte vendicionis a dicto emptore ypp. LXXV.

Die sexto aprilis MCCCLXXXX primo

Suprascriptus magister Johannes fuit confessus recepisse a suprascripto Sthoyco...

(DADU, Vend. Canc., 4, f. 45r)

\section{2.}

Zlatar Dobre Pribisalić 1441. godine prodaje Ivanu Markovom kuću u seksteriju sv. Vlaha za 370 perpera.

\section{MCCCCXLI die XVIIII junii}

Dobrie Pribisalich aurifex titulo et nomine venditionis iure proprii imperpetuum dedit, tradidit et vendidit unam do- mum positam in sexterio Sancti Blaxii super terreno archiepiscopatus quam dictus Dobrie emit ab epitropis testamenti quondam Radossavi Rutosevich prout de dicta emptione patet in venditionibus cancellariae sub die XV junii 1438 ad cartam 234; confinat a parte levantis cum domo infrascripti emptoris et a parte tramontane cum domo Naleschi ortolani, et a parte austri cum domo Radule uxoris Tuerdisse, et a parte ponentis cum via comunis cum omnibus suis iuribus et pertinentiis, et cum angaridio grossi XVIII, parvuli XX solvendorum singulo anno archiepiscopatui, Johanni de Marco ibi presenti, et pro se et suis heredibus et successoribus recipienti et ementi precio et foro ypp. tricentorum (!) septuaginta, videlicet ypp CCCLXX.

Cum hac condicione quod dictus emptor non possit per venditorem nec aliquam aliam personam astringi ad depositandum dictum precium in camera donec non fuerint cassi omnes apresentati.

Die XI septembris 1443 (in margine: Proclamatio)

Mandato domini consulis causarum civilium comunis Ragusii ser Nicole Si. de Goze, et suorum judicum ser Nicole Jo. De Caboga, ser Damiani de Menze, ser Damiani de Sorgo et ser Sigismundi de Georgio, Luxa riverius comunis retulit se publice in locis solitis et consuetis proclamasse suprascriptam vendicionem de verbo ad verbum, et in fine dixisse unde si quis et cetera in omnibus et per omnia secundum ordines.

Texaurarii Sancte Marie (die XXIII novembris 1444 cassa de voluntate ser Johannis de Volzo texaurarii Sancte Marie et ser Nicole Si. de Goze vicetexaurarii)

Procuratores Sancte Marie (die XVIII junii 1444 cassa de voluntate ser Nicole Jo. de Poza et ser Thome de Sorgo procuratores Sancte Marie)

Procuratores Sancti Blaxii (die XVIII junii 1445 cassa de voluntate ser Marini Mi. de Resti et ser Andree de Babalio procuratores Sancti Blaxii)

Camerarii comunis ( $\{$ in margine: Sententia\} Die XI marcii 1444 dominus consul causarum civilium comunis Ragusii ser Marinus Mi. de Bona una cum suis iudicibus ser Johanne de Volzo, ser Marino Mi. de Restis, ser Nicola Jo. de Caboga, ser Damiano de Sorgo et ser Nicola Pau. de Gondola, viso quod dato termino camerariis XV dierum non fuit repertum comune debere habere quidquam terminavit et sentenciavit dictam presentacionem camerariorum et sic fuit cassa de eorum mandato.)

(in margine: Solutio)

Dobrie Pribisalich venditor ultrascriptus die XXV februarii 1446 confessus fuit quod habuit et recepit a Johanne Marci emptore ultrascripto dante et solvente pro conpleta solutione ultrascripte vendicionis ipp tricentos septuaginta. Renunciando.

ypp. CCCLXX

[Extradata die XXVII februaris 1446 sub atestacione ser Zupani de Bona iudicis et Nicole Stelle testis]

(DADU, Vend. Canc., 9, ff. 8rv) 


\section{Bilješke}

1

VINKO FORETIĆ, Dubrovački arhiv u srednjem vijeku, u: Anali Historijskog instituta JAZU u Dubrovniku, 6-7 (1959.), 328. Premda su i u prijašnjem razdoblju dokumenti ove vrste bili vođeni u zasebnim sveščićima, naposljetku su bili uvezani s ostalima, usp. kupoprodajne dokumente iz trinaestog stoljeća objavljene u: Spisi dubrovačke kancelarije, knjiga I. (Zapisi notara Tomazina de Savere 1278.-1282.) (dalje Spisi dubrovačke kancelarije, knjiga I.), (ur.) Gregor Čremošnik, Zagreb, 1951.

2

Državni arhiv u Dubrovniku (dalje DADU), Venditiones Cancellariae (dalje Vend. Canc.), HR-DADU-16. Svesci koji su uključeni u analizu predstavljenu u ovome radu su sljedeći: sv. 1 (1352.-1361.), sv. 2. (1365.-1379.), sv. 3 (1371.-1382.), sv. 4 (1382.-1386.), sv. 5 (1419. -1427.), sv. 6 (1428.-1433), sv. 7 (1433.-1438.), sv. 8 (1438. -1441.). sv. 9 (1441.-1443.), sv. 10 (1443.-1446.), sv. 11 (1446. -1448.), sv. 12 (1449.-1451.) i sv. 13 (1451.-1454.).

3

LUJO VOJNOVIĆ, Dubrovačko-gruške prodaje kuća i ulice staroga Dubrovnika (XIV.-XVII. vijeka), u: Rad JAZU, 82 (1913.), 101-123. Vojnović je proučavao popise "Dal Indice di Matteo Marino de Buchia che principia dal 1522 fino al 1667. Vendite delle case in Ragusa" te "Vendite delle terre e case di Gravosa, dal 1350 al $1667 \ll$.

4

LUJO VOJNOVIĆ (bilj. 3), 117-122.

5

LUJO VOJNOVIĆ (bilj. 3), 102, 106.

6

ŠIME LJUBIĆ, Popis prodaja dubrovačkih iz XVI. stoljeća, u: Starine, 11 (1879.), 1-18. Rukopisi koje je Ljubić istraživao su: »Vendite di Canali, Terre Noue, Stagno e Ponta di Stagno de 1350 in 1728 et ultra « $\mathrm{i}$ »Vendite di Breno, Bergatto, Bosanska, Plocce, Gionchetto, Ombla, Losizza, Varbizza, Malfo et Obrovo del 1350 in 1634 et ultra».

7 ŠIME LJUBIĆ (bilj. 6), 1-2.

8

JOSIP GELČIĆ, Dubrovački arhiv, u: Glasnik Zemaljskog muzeja u Bosni i Hercegovini, 22 (1910.), 582. Signature prema Novom ustroju fondova Dubrovačke republike i francuske uprave su XVI. a i XVI. b. Knjige, koje danas poznajemo pod ovim nazivima, u četrnaestome su se i petnaestom stoljeću nazivale »quaderni/ libri venditionum $\ll$.

9

O nekim nedosljednostima u Gelčićevoj katalogizaciji arhiva vidi: NELLA LONZA, Srednjovjekovni zapisnici dubrovačkog kaznenog suda: izvorne cjeline i arhivsko stanje, u: Anali Zavoda za povijesne znanosti HAZU u Dubrovniku, 41 (2003.), 46.

10

Nekoliko je istovjetnih primjera registara koji su spletom često nepoznatih okolnosti uvezeni u različite cjeline, vidi npr. NELLA LONZA - ZDENKA JANEKOVIĆ RÖMER, Dubrovački "Liber de maleficiis" iz 1312.-1313. godine, u: Radovi Zavoda za hrvatsku povijest Filozofskog fakulteta Sveučilišta u Zagrebu, 25 (1992.), 173-174.

11

IGNACIJ VOJE, Kreditna trgovina u srednjovjekovnom Dubrovniku, Sarajevo, 1976., 25.
12

O tome opširnije v. u uvodu G. Čremošnika u Spisi dubrovačke kancelarije, knjiga I. (bilj. 1), XI-XII.

13

Ipak, manji se dio miraza mogao podmiriti nekretninom, što je bilo dopušteno prema dubrovačkome Statutu: Statut grada Dubrovnika: sastavljen godine 1272., na osnovi kritičkog izdanja latinskog teksta Baltazara Bogišića i Konstantina Jirečeka (dalje Statut), (ur.) Ante Šoljić i dr., Dubrovnik, 2002., Lib. IV, Cap. I (De dote et perchivio), 240-243.

14

Liber viridis (dalje Liber viridis), (ur.) Branislav N. Nedeljković, Beograd, 1984., 431 (incantus taciti et venditionumque).

15

Lastovski statut, (ur.) Antun Cvitanić, Split, 1994., Cap. CLVIII, 287,440 . Statut datira iz 1310. godine, ali sadrži brojne naknadne izmjene i dopune.

16

U Knjizi rizničarskih najmova u dva se navrata poziva na »venditte tazite in notaria $\mathrm{i}$ »libro de vendite tazite in nottaria «; Knjiga rizničarskih najmova = Liber affictuum thesaurarie (1428.-1547.), (ur.) Danko Zelić, Zagreb - Dubrovnik, 2012., 217, 285.

17

Statut (bilj. 13), Lib. VIII, Cap. 72 (De hiis qui habent jus in re stabili vendita, et sunt absentes tempore preconiçationis), 482-483.

18

Statut (bilj. 13), Lib. VIII, Cap. 74 (De hiis qui se presentant venditionibus et vadunt extra Ragusium), 484-485.

19

DANKO ZELIĆ, Proclamationes šibenskog kneza Fantina de Cha de Pesaro (1441.-1443.), u: Povijesni prilozi, 35 (2008.), 161; TOMISLAV POPIĆ, Mechanisms of Immovable Property Transfer in a Medieval Town: The Case of Zadar, $\mathrm{u}$ : Towns and Cities of the Croatian Middle Ages: Authority and Property, (ur.) Irena Benyovsky Latin - Zrinka Pešorda Vardić, Zagreb, 2014., 478, 484.

20

Additum est tempore egregii militis d. Marini Badoarii, comitis Ragusii quod tabula una ponatur ante Lodiam in qua scribantur omnes vendiciones, et stent per spacium trium mensium, Statut (bilj. 13), Lib. 5, Cap. 35 (De preconiçacione rei que vendi debet), 314-315.

21

(...) [zonta] incantata fuit pluribus diebus in ecclesia Sancti Blasii per Matheum de Risa plana voce secundum usum tandem deliberata fuit, Vend. Canc., 5, f. 125v.

22

Locus autem dictorum incantuum venditionum de cetero sit et esse debeat sub logia communis, videlicet sub tecto ipsius logie, Liber viridis (bilj. 14), Cap. 488 (Ordene che non se incanta gabelle le domenege), 431-432. O polivalentnom prostoru luže crkve sv. Vlaha vidi: ANA MARINKOVIĆ, Kasnosrednjovjekovna crkva sv. Vlaha, u: Zborna crkva Sv. Vlaha u Dubrovniku, (ur.) Katarina Horvat-Levaj, Dubrovnik - Zagreb, 2017., 85.

23

(...) in logia magna ubi banditio predicta fiebat, Vend. Canc., 5, f. 196 r.

24

Captum fuit de eundo ad maius consilium quod ad quamlibet vendicionem factam per cridam cancelarii scribant procuratores 
hospitalis comunis prout scribunt tesaurarios, camerarios et procuratores Sancte Marie et Sancti Blasii, DADU, Reformationes, 33, f. 192r. Citirani dio dokumenta objavljen je na mrežnim stranicama projekta Dubrovnik: Civitas et Acta Consiliorum. Visualising Development of Medieval Urban Fabric, URL: https://ducac.ipu. hr/project/mapping/diversa/ (19. 7. 2017.).

25

NADA GRUJIĆ, Kuća u Gradu: studije o dubrovačkoj stambenoj arhitekturi 15. i 16. stoljeća, Dubrovnik, 2013., 29.

\section{6}

Usp. GORDAN RAVANČIĆ, Kvantifikacija svakodnevnice - primjer dubrovačkih krčmi, u: Povijesni prilozi, 39 (2010.), 11-21.

\section{7}

LUKŠA BERITIĆ, Urbanistički razvitak Dubrovnika, Zagreb, 1958., 13-23; DANKO ZELIĆ, Wooden Houses in the Statutes and Urban Landscapes of Medieval Dalmatian Communes, u: Splitski Statut iz 1313. godine: Povijest i pravo. Povodom 700. obljetnice. Zbornik radova sa međunarodnoga znanstvenog skupa održanog od 24. do 25. rujna 2012. godine u Splitu, (ur.) Żeljko Radić i dr., Split, 2015., 489-507.

28

Vend. Canc., 7, f. 233r; 9, f. 113r, 129r; 12, f. 139v; 13, f. 188r.

29

Domus magna (...) in qua presentaliter habitat, Vend. Canc., 5, f. $128 \mathrm{v}$

30

IRENA BENYOVSKY LATIN, Smještaj gradskog plemstva u dalmatinskim gradovima srednjeg vijeka, u: Acta Histriae, 16/1-2 (2008.), 40.

\section{1}

IRENA BENYOVSKY LATIN - SANDRA BEGONJA, Nekretnine u notarskim dokumentima 13. stoljeća: primjeri dalmatinskih gradova (Zadra, Šibenika, Trogira, Splita i Dubrovnika), u: Povijesni prilozi, 51 (2016.), 10, 12-13.

32

JOSIP LUČIĆ, Prinosi građi srednjovjekovnog latiniteta (capanna, casale, curia, homo, domus, rusticus, sella, villa, villanus), u: Arhivski vjesnik, 9 (1966.), 294-296.

33

Casale sive terrenum, Vend. Canc., 5, ff. 158v, 255v; casale (...) longum videlicet a levante versus ponentem passis novem cum vel circa et amplum ab austrio versus tramontana passis tribus cum dimidio vel circa, Vend. Canc., 5, f. $127 \mathrm{v}$; terrenum sive casale passibus tribus, Vend. Canc., 5, f. 201v.

34

Casale cum omnibus lapidibus, calce, savorna et terreno in ipso casali existentis, Vend. Canc., 7, f. 121v; casale (...) cum omnibus lapidibus que sunt in dicto casale, DADU, Diversa Cancellariae (dalje: Div. Canc.), 28, f. 6r. Na takav zaključak upućuju i uvjeti prodaje među kojima se pronalaze i dozvole gradnje zidova, vidi: Vend. Canc., 4, f. 67r; 7, f. 192r.

35

MARIJA PLANIĆ-LONČARIĆ, Zajednički prostori stambenih zona srednjovjekovnog Dubrovnika, u: Radovi Instituta za povijest umjetnosti, 12-13 (1988.-1989.), 69-71.

36

Vend. Canc., 5, f. $167 \mathrm{v}$.

37

Vend. Canc., 9, f. 82v.
38

Prva je prodaja, 1423. godine, bila poništena jer ju je prodavatelj, ser Mihovil pokojnog Šimuna Restića, objavio bez Paskoja Restića, koji je pak 1425. istome kupcu, Antoju Butkovome, nekretninu prodao za mnogo veći iznos; Vend. Canc., 5, ff. 127v, 201v.

39

Pojedini istraživači govore o 'nekretninskom boomu' trinaestog stoljeća u seksteriju sv. Vlaha, ŽELJKO PEKOVIĆ - KRISTINA BABIĆ, Vlasnički odnosi u Dubrovniku u stambenom bloku zapadno od Ulice Miha Pracata u drugoj polovini 13. stoljeća, u: Starohrvatska prosvjeta, III, 43 (2016.), 269.

40

Više o seksteriju Sv. Nikole vidi u: DANKO ZELIĆ, Medieval Urban Landscape of the Northern Part of the City of Dubrovnik (1372-1450), u: Mapping Urban Changes, (ur.) Ana Plosnić Škarić, Zagreb, 2017., 264-287.

41

O dubrovačkim seksterijima, s pregledom starije literature, vidi: IVANA LAZAREVIĆ, Granice dubrovačkih seksterija, u: Anali Zavoda za povijesne znanosti HAZU u Dubrovniku, 50 (2012.), 63-74.

42

Ponekad se uz seksterije Kaštela miješa i seksterij Pustijerne. Tako se prodaje kuća smještena »in sexterio Sancte Marie de Castello in contrata Pusterne«, Vend. Canc., 10, f. 167r; ili pak kuća koja se nalazi u seksteriju sv. Marije od Kaštela, ali graniči s crkvom sv. Stjepana, Vend. Canc., 6, f. 130r.

43

Istovjetne primjere ove prakse navodi i LUKŠA BERITIĆ, Ubikacija nestalih gradjevinskih spomenika u Dubrovniku, u: Prilozi povijesti umjetnosti u Dalmaciji 10 (1956.), 19.

44

U pojedinim se dokumentima teren u vlasništvu nadbiskupije, zvan Garište, (pogrešno) smješta u seksterij sv. Marije, Vend. Canc., 5, f. 23v; 13, f. 97v.

45

(...) domus cum scala et archivolto (...) in sesterio sancte Marie, apud ecclesiae Sancte Jellene, Vend. Canc., 13, f. 8v. O položaju crkve vidi: LUKŠA BERITIĆ (bilj. 43), 52-53.

46

Tako se teren nadbiskupije, koji se približno prostirao od samostana sv. Klare do Široke ulice, i time nedvojbeno bio dijelom seksterija sv. Vlaha, ponekad navodi u seksteriju sv. Marije, Vend. Canc., 5, f. 23v; 7, f. 158r; 13, f. 97v.

47

S pregledom mišljenja u starijoj literaturi: ŽELJKO PEKOVIĆ KRISTINA BABIĆ (bilj. 39), 270-271 (bilj. 57, 58).

48

LUKŠA BERITIĆ (bilj. 43), 18-19. Usporedi i ŽELJKO PEKOVIĆ - KRISTINA BABIĆ (bilj. 39), 271 (bilj. 57).

49

Vend. Canc., 1, f. 162r.

50

U seksteriju sv. Vlaha navode se kuće sa sljedećim odrednicama: "in contrata post monasterium puellarum «, Vend. Canc., 7, f. $213 \mathrm{v}$, "prope ecclesiam monasterii Sancti Marcii«, Vend. Canc., 7, f. 49r, te »subtus capanam ecclesiae Sancti Marci«, Vend. Canc., 4, f. 86r.

51

Za razliku od brojnih primjera za prvi slučaj, tek je jedan za drugi: Vend. Canc., 7, f. 219r. 
52

Vend. Canc., 5, f. 74v; 8, f. 51v; 9, f. 115r; 10, f. 4r.

53

Vend. Canc., 11, ff. 6r, 13r.

54

Zanimljivo je da se ni za seksterij sv. Nikole, u kojemu se u sličnim istovremenim izvorima ulice nazivaju prema brojevima (od prve do petnaeste, $\mathrm{u}$ smjeru od istoka prema zapadu), ne koristi to nazivlje. Postoji tek jedna iznimka kuće »in ruga nona«, Vend. Canc., 7, f. $211 \mathrm{v}$.

55

Vend. Canc., 5, f. 161v.

56

Vend. Canc., 4, f. 70r.

57

U seksteriju sv. Nikole: "ruga Sancti Francisci« (Vend. Canc., 9, f. $117 \mathrm{r} ; 12$, f. 114v), »ruga Sancti Segurati« (Vend. Canc., 8, ff. 23r, 26r; 11, 21r), "ruga sanctorum Petri, Laurenti et Andree" (Vend. Canc., 5, f. 133v), te "ruga Sancti Nicolay« koja je navedena u seksteriju sv. Marije, premda se vjerojatno radi o pogrešci (Vend. Canc., 5, f. 114v). Bez oznake seksterija se pojavljuje »ruga ecclesiae Sancti Michaelis de labibus« (Vend. Canc., 3, f. 180r). Termin contrada se susreće u sljedećim primjerima: "contrata post monasterium puellarum " (Vend. Canc., 7, f. 213v) te "contrata Sancte Marie de Castello« (Vend. Canc., 12, f. 86v).

58

Ulica se spominje u prodajama čak trinaest nekretnina: Vend. Canc., 2, ff. 20v, 28r, 34r, 38r, 41v, 42r, 47rv, 48v, 96v, 108r, 114v; 3 , f. 109 v; 5 , f. 211 v.

59

Ruga Givchi Nichi de Chaboga, Div. Canc., 28, f. 6v.

60

Ruga Milgosti staçionari, Vend. Canc., 2, f. 18r.

61

Ruga quondam Junii de Georgio, Vend. Canc., 2, f. 26 r.

62

Ruga ubi habitat Luxa bastasius, Vend. Canc., 11, f. 159r.

63

Vend. Canc., 12, f. 135v. Moguće je da se radi o ulici Slavce koju neki drugi suvremeni izvori bilježe u susjednom seksteriju sv. Vlaha, kako je zabilježeno 1429. godine u odluci Maloga vijeća, DADU, Acta Minoris Consilii, 4, f. 241v. Dokument je objavljen na stranici projekta DUCAC (bilj. 24). URL: https://ducac.ipu. $\mathrm{hr} /$ project/mapping/b4-segment/b4-ruga-slavze/ (19. 7. 2017.).

64

Vend. Canc., 2, f. 116v.

65

Ruga ser Gançe de Poza, Vend. Canc., 5, f. 99v.

66

Ruga Dabisiv de Latiniz, Vend. Canc., 8, f. 137v.
67

Vend. Canc., 7, f. 129v.

68

Usp. VALENTINA ZOVKO, Socijalna topografija Dubrovnika krajem 13. i početkom 14. stoljeća na primjeru obitelji de Sorgo (Sorkočević), u: Povijesni zbornik, 4 (2009.), 17-33.

69

Territorium (...) supra quod territorium edificate sunt due domus de muro Goyachi marangoni et domus una Ivanis marangoni, Vend. Canc., 6, f. 41v.

70

Statut (bilj. 13), Lib. V, Cap. XXXV (De preconiçacione rei que vendi debet), 314-315.

71

NENAD VEKARIĆ, Vlastela grada Dubrovnika, sv. 8 genealogije (M - Z), Zagreb, Dubrovnik, 2017., 389.

72

Spisi dubrovačke kancelarije: zapisi notara Andrije Beneše. Praecepta rectoris II (1299.-1301.) i Testamenta II (1295.-1301.), (ur.) Josip Lučić, Zagreb, 1993., 41, 45, 89.

73

In dicto maiori consilio captum fuit et firmatum per consiliarios LVIII existentibus consiliaribus LX, quod illi qui habeant domos super teritorio illorum de Sueri, si voluerint facere domos de muro vel de macerie, debeat eis firmari dictum terrenum in perpetuum solvendo affictum consuetum tam de vacuo quam de pleno, Liber omnium reformationum, (ur.) Aleksandar Solovjev, Beograd, 1936., Cap. 17 (De domibus de Sueri), 88.

74

(...) [vendidit] tota sua ratione, actione et potestate unius teritorii illorum de Svieri ubi dictus Martinus olim habuerat domum lignaminis que fuit conbusta et totum laborerium factum super dicto territorio et omnes lapides qui sunt ad presens, Vend. Canc., 3, f. 85r. Za ostala dva dokumenta vidi: Vend. Canc., 2, ff. 27r, 34r.

75

Cum angaridio gross XXX qui solvuntur annuatim illis de Suiri, Vend. Canc., 6, f. 110v.

76

ŽELJKO PEKOVIĆ - KRISTINA BABIĆ (bilj. 39); IRENA BENYOVSKY LATIN - STIPE LEDIĆ, Posjed obitelji Volcassio u srednjovjekovnom Dubrovniku, u: Anali Zavoda za povijesne znanosti HAZU u Dubrovniku, 51 (2013.), 17-60.

77

Ovom prilikom nije bilo riječi o također važnom segmentu Venditiones Cancellariae, cijeni prodavanih kuća, ili pak visini tereta koju su vlasnici kuća bili obavezni plaćati. O cijenama ukratko u: MATKO MATIJA MARUŠIĆ, Mapping Housing Market in Late Medieval Dubrovnik: The Saint Nicholas sexterium (ca. 1420-1450), u: Mapping Urban Changes, (ur.) Ana Plosnić Škarić, Zagreb, 2017., 296-298. 


\section{Summary}

\section{Matko Matija Marušić}

\section{Urban Landscape and Property Ownership in Late Medieval Dubrovnik: The Venditiones Cancellariae Series}

This paper presents the results of research on the Venditiones Cancellariae series, preserved at the State Archive of Dubrovnik. The analysis is based on the first thirteen volumes of the series, covering the period from 1352-1454. The introduction includes some basic information on the content of the series and the differences between the individual volumes. The problem of missing documents for a thirty-year period (from 1386-1417) is discussed, indicating that the said documents may not be lost, but simply added to another series, as was the case with Book 28 of the Diversa Cancellariae and Book 6 of the Debita notariae. The structure of sale contracts and their elements are analysed, with a transcription of two typical documents: sale of the house owned by master stonemason Jean de Vienne (1386) and goldsmith Dobre Pribisalić (1441). Besides comparing some documents from the $14^{\text {th }}$ and $15^{\text {th }}$ centuries, the author briefly describes their legal basis as well as the process of real-estate transactions, which begins with an agreement between the parties, publicly announced in a proclamation, and ends with the payment of the agreed sum of money.

The second part of the article focuses on a specific research interest that motivates the study of these insufficiently known volumes. Based on the information collected from 1147 transactions related to real estate within the city walls, the author discusses the urban landscape and property topography of late medieval Dubrovnik, referring to specific types of real estate that appear in sale contracts and clarifying certain terms used there (casale, domus magna). Special attention has been paid to place names in medieval Dubrovnik, whereby various hitherto unknown names of micro-locations called after prominent individuals have been singled out. Regarding the fact that the borders of Dubrovnik's sexteria are still unknown, the author has used the data from the Venditiones Cancellariae to define the spatial coordinates of individual parts of the city, which is explained on the example of the sexterium of St Blaise. Eventually, the issues of land-plot ownership and lease payment (angaridium or terraticum), which house owners were obliged to pay, are discussed. The data analysis has been presented in the form of graphs, and several examples have been used to indicate the possibilities of further research on this still insufficiently known archival series.

Keywords: urban history, property topography, urban development, sale contracts, Venditiones Cancellariae, State Archive in Dubrovnik 